\title{
Accounting Talent Training Reform in the Era of Artificial Intelligence
}

\author{
Yan $\mathrm{Ma}^{1, *}$ \\ ${ }^{1}$ School of Accounting, Nanjing University of Finance \& Economics, Nanjing, Jiangsu 210046, China \\ *Corresponding author.Email: yanma@nufe.edu.cn
}

\begin{abstract}
Under the rapid development of new generation information technology represented by big data, artificial intelligence, mobile Internet, cloud computing, Internet of things and blockchain and the development strategy based on "intelligence +", the traditional knowledge framework and professional skills of accounting talents have been quickly subverted and replaced. The cultivation of innovative intelligent accounting talents has become a hot topic in the industrial and educational circles. The training of intelligent accounting talents needs to clarify the object of their service and determine the scope, development law and trend of their connotation. Firstly, based on the analysis of the development background, the nature of its social activities is defined and the theoretical framework is constructed; Secondly, its goal, essence, function, characteristics and technical framework are analyzed; Finally, the training standard of intelligent accounting talents is established and a characteristic, reference and integrated accounting training scheme is designed. We actively explore the construction and innovative talent training mode of intelligent accounting specialty, provide the basis and path for the reform of accounting specialty in colleges and universities, and realize the common prosperity of education.
\end{abstract}

\section{Keywords: Artificial Intelligence, Accounting Talent Training, Innovation, Digital Economy}

\section{INTRODUCTION}

With the development of a new generation of information technology, the lifestyle and management mode of human society have undergone complex, systematic and profound subversive changes. With the deep integration of new technology and social economy, digital economy presents the development trend of high-frequency innovation and has become the key driving force of global economic growth. Under the promotion of information technology, accounting education gradually lags behind the development of digital economy, and has been severely impacted and challenged. Many daily financial work is gradually replaced by intelligent robots [1-2]. The mismatch between supply and demand of primary accounting talents with financial accounting ability as the core makes the discussion of whether the accounting profession will die out deeply concerned by all sectors of society. The training mode of accounting talents, which is the main focus on accounting with bookkeeping, balancing the books and reimbursement as the main contents will be or have been replaced by intelligent robots, with learning "accounting standards" as the main content, mastering "accounting entries" as the main requirement, being familiar with "accounting cycle" as the main process, filling in "bill and certificate account tax" as the main skill, and strengthening "classroom teaching", will eventually be replaced by the intelligent accounting education mode[5].

The development of intelligence accounting in China has experienced three stages: the stage of financial computerization based on enterprise customized accounting software (accounting computerization); The information age of preliminary integration of business management and financial management (information / industry finance integration); With the gradual maturity of technologies, enterprises begin to apply financial cloud, RPA and other products to assist senior management decision-making through financial analysis and enter the stage of financial intelligence (intellectualization).

The financial position in the computerization stage requires accountants to have solid financial professional knowledge, master the accounting process with bookkeeping, accounting and reimbursement as the main contents, ensure the accuracy of financial report data, and focus on the financial management with "fiscal and tax money" as the core.

One side, the financial position in the information stage requires accountants to have solid financial professional knowledge, on the other side, they skillfully use the basic computer programming technology and statistical analysis tools to select the required data for the data integrating the functions of multiple systems such as finance, OA, ERP and supply chain management, and reflect the business performance of the enterprise through financial data analysis. So as to support business investment, strategy and risk audit departments [8].

The accounting profession in the intelligent stage requires accountants to master financial professional knowledge, have the ability of big data analysis, and the ability to create value by using artificial intelligence, deep learning and other technologies[3] [6]. The content of accounting work 
is to continuously integrate intelligent technologies such as data science, machine learning, deep learning, cognitive analysis and RPA into financial work, use big data analysis technology to mine value from massive data in the whole process of enterprise industrial chain and value chain, improve fund use efficiency, predict fund management and control risks and promote enterprise value creation. Financial personnel are transforming from value guardian to value creator, engaging in creative and decision-making work, and pursuing the embodiment of human "value". On the basis of improving professional knowledge, strengthening data analysis ability is undoubtedly one of the important paths for the development and transformation of financial personnel [7].

\section{CONNOTATION OF INTELLIGENT ACCOUNTING AND RECONSTRUCTION OF TALENT TRAINING}

The essence of accounting is an important part of economic management. It collects economic information, takes money as the main unit of measurement, comprehensively, continuously and systematically calculates and supervises the economic activities in the process of social reproduction, transmits the information of economic activities, and provides the performance of entrusted responsibilities for the users of accounting information, help enterprise managers make various decisions. Therefore, as long as the enterprise decision-making needs the support of financial information, the logic, procedures and methods used to generate financial information comply with the law of economic activities, the accounting profession and financial posts will not die out. The more economy develops, the more important accounting is. With the increasing complexity and risk of the capital market, the value of financial data and information rises. The importance of accounting talents to management decision-making becomes more prominent. However, the storage, content and analysis tools of data and information have changed greatly with the development of information technology. The knowledge structure of accounting talents is facing transformation and improvement, and the training mode of accounting professionals must be reconstructed.

As the development direction of accounting in the future, intelligent accounting needs to clarify four problems in the reconstruction of talent training mode of accounting specialty: firstly, what is intelligent accounting? It lays the content and boundary of intelligent accounting specialty; Secondly, what kind of ability intelligent accounting talents need to have? It defines the ability framework of talent training to guide the training scheme and curriculum system design; The third is the ways and methods used to cultivate talents' ability. That is, what teaching contents need to be redesigned or reformed, and what teaching methods are used; Finally, how to evaluate the effectiveness of the reform? It designs an assessment system which meets the requirements of training ability, and ensures that the effectiveness of the reform meets the talent training objectives.

\subsection{Connotation of Intelligent Accounting}

According to the development process of intelligence, this paper believes that intelligent accounting is essentially a management activity, which takes digital economy as the premise, industry finance integration as the basis, financial sharing as the platform and artificial intelligence as the support. It mainly gives play to big data analysis and auxiliary decision-making information to improve the efficiency and effect of management in the field of macro and micro economic management. Furthermore, it is an accounting management activity to realize and expand the financial and accounting function and its strategic value. The future development direction of accounting is intelligent accounting, which is essentially how to improve efficiency. According to the logic of technological development and its promotion, intelligent accounting is the product of mutual connection, interdependence, integration and penetration of accounting science, data science and computer science on the basis of artificial intelligence and other technologies[4]. It is an interdisciplinary category of data and has the scientific attribute of computer accounting. It at least involves the comprehensive intelligence of accounting, accounting supervision, accounting planning, accounting prediction, accounting decision-making, accounting budget, accounting control, accounting evaluation and accounting sharing.

\subsection{Ability Structure of Intelligent Accounting Talents}

Financial management activities have been making continuous progress with the development of technology. The development of technology is also promoting the management activities of enterprises, which can better create value for enterprises. With the development of artificial intelligence technology, it has put forward higher requirements for professionals in accounting and financial management departments to improve the efficiency of financial management decision-making by modeling and analyzing big data such as internal, external, macro and micro data of enterprises.

In the design of the training program, the company's financial and artificial intelligence will increase the data compound training as the purpose. It reflects the knowledge system of cross domain and cross professional collaborative innovation in the training program and curriculum design, and trains students to have cross-border compound knowledge background when facing the challenges of new technology. So that the talents trained by intelligent accounting specialty, on the one hand, have profound professional knowledge of financial accounting and international strategic vision, but also have the ability of data analysis and technological innovation[9]. Based on the 
above judgment, this paper constructs the ability framework of intelligent financial talents including six abilities, and then puts forward the corresponding training requirements.

\subsubsection{Ability to handle accounting business and manage finance}

The talents must have excellent professional knowledge, and have certain cultivation in production and operation management, philosophy, sociology, marketing, management psychology, etc., so as to produce a "professional power" beyond its authority.

\subsubsection{Excellent accounting language communication and teamwork skills}

Cultivate talents with the ability to communicate in accounting language and good interpersonal skills, so that people have a sense of admiration for them, so as to carry out their work effectively.

\subsubsection{Have the ability of independent learning and innovation iteration}

With the development of artificial intelligence, the knowledge reserve of trained talents should keep up with the development of enterprises or industries. Only by continuously improving the knowledge structure, thinking mode and post responsibilities of talents can we gain a foothold. In practical work, we should have strong enterprising spirit and the ability to explore and innovate. We should strengthen learning, constantly update knowledge, change ideas and comply with the requirements of the development of market economy; Cultivate good memory, keen observation, rich imagination and rigorous thinking ability.

\subsubsection{Have the ability to master big data analysis methods and technologies and modern information technology analysis tools}

In the era of digital economy, the position of the financial department as the enterprise information center will be more prominent, and the information processing ability will directly affect the effect of financial management. In a world full of information, information processing capability is a process of transforming data into decision-making wisdom, and the financial department has changed from an information storer to an information provider and sharer. Financial managers need to learn how to turn data into information, and then from information into knowledge. Finally, decision makers convert knowledge into decisionmaking wisdom, and put decisions into action through the financial department.

\subsubsection{Have the ability of systematic accounting thinking}

Intellectualization will help to integrate financial accounting, management accounting and cost accounting into the development trend of "big accounting". This kind of big accounting thinking ability should be critical, creative and systematic. In essence, it is a mode of overall thinking and comprehensive problem-solving. The cultivation of " big accounting " thinking ability runs through the whole process of accounting course teaching system, which helps to improve students' professional competence, enhance students' career development flexibility, and better realize the connection between teaching and market demand.

\subsubsection{Have the ability of intelligent accounting prediction, budget, decision-making, control and evaluation}

Decision making ability comes from the depth, breadth and rich practice of personal knowledge. Knowledge is accumulated at ordinary times, which is composed of political, economic, legal knowledge and professional cultural quality. While rich practical experience is formed by the combination of comprehensive skills and direct and indirect experience mastered in specific business operation.

\subsection{Curriculum System Reform}

In terms of teaching content, the model of "theoretical learning in the first classroom + practical lectures in the second classroom, student activities + practical learning in winter and summer" can be adopted. First, adjust the structure of the training program, pay attention to the study of comprehensive financial knowledge, and appropriately reduce the proportion of financial accounting. The accounting informatization course integrates artificial intelligence, big data and other contents. The informatization turn into accounting intelligence.

Secondly, strengthen the learning of business process, master the audit control process of business content, and audit contracts, warehousing procedures and relevant bills. Then, reconstruct the accounting practice training system. The professional curriculum experiment includes the internal curriculum experiment of relevant courses, the basic experiment of accounting specialty, the comprehensive experiment of accounting specialty, etc. Course experiments and professional basic experiments are mainly based on the explanation of knowledge points, and experiments are carried out while giving lectures; The comprehensive experiment integrates the learned professional knowledge, focuses on specific practical cases, and completes the research scheme through group discussion. The second classroom activities include social practice, reading activities, comprehensive writing, speech communication, accounting knowledge competition, financial statement reading competition of listed companies, 
green accounting publicity, personal social responsibility report writing, social volunteers, etc; In addition to the class activities, it also includes organizing CMA case competition, AIA case competition, financial case competition, audit case competition, business management case competition, ERP sand table competition, and Internet plus competition.

Finally, promote school enterprise cooperation and realize the dual cultivation of school-enterprises in the whole process of students from enrollment to graduation.

\subsection{Evaluation Mechanism}

Balance theoretical literacy and practical experience. Take joint examination, students correcting each other, students themselves examinations that students themselves out, application examination system and other ways, and take theoretical literacy and practical experience as the two key points of the examination content. Highlight the examinee's ability to use basic knowledge and theoretical analysis to solve practical problems, and evaluate the students' ability to use knowledge flexibly.

Research teaching and research-based learning can be implemented to cultivate students' research ability to find problems and practical ability to solve problems. Some research-based learning courses can include course papers into the usual performance assessment[10].

Students in the class are encouraged to actively participate in the internship of large enterprises and institutions, understand enterprise accounting practice and apply the theories and tools of intelligent accounting without affecting their study and personal safety in the school.

\section{CONCLUSION}

Intelligent accounting can optimize the speed of information processing and improve the efficiency of accounting under the influence of reducing human factors; Reduce information distortion and errors, so as to improve the accuracy of data processing, efficient financing, improve the core competitiveness of enterprises and optimize the structure of financial personnel. For the accounting industry: it will change the operation mode of work and information; For Accountants: it will change the concept of accountants and change the ability level at the same time. Intelligent accountants are accountants who keep pace with the times, cross-border thinking, management, big data and create value.

Intelligent accounting major has the knowledge and ability of management, economics and other related disciplines, and has the integrity, humanity and scientific spirit. Intelligent accountants have mastered the accounting, management, economics, law and computer application, and been suitable for the financial shared service mode under the internet plus environment, and also known that the application of artificial intelligence and big data in accounting related decisions. Compound innovative professionals with independent research ability, practical ability and communication skills, who can be competent for intelligent accounting and related work in large (financial) enterprise groups, large intermediaries, high-level government institutions and public institutions.

In order to achieve this goal, on the basis of strengthening professional basic knowledge, modern computing and information technology are integrated into the curriculum content; The professional knowledge structure and ability framework of intelligent accounting talent training are comprehensively reconstructed; The curriculum system is reformed and the evaluation mechanism is given. Implement the reform of accounting specialty and give full play to its effectiveness.

\section{REFERENCES}

[1] CPAC (Chartered Professional Accountants of Canada). Big Data and Artificial Intelligence. The Future of Accounting and Finance, 2019.

[2] Tang Dapeng, Wang Bolun, Liu Yichen.

Reconstruction of accounting education in the era of "digital intelligence": contradiction between supply and demand and factor innovation [J]. Accounting research, 2020.(In Chinese)

[3] Bhaskar, P., Tiwari, C. K., \& Joshi, A.(2020). Blockchain in education management: present and future applications. Interactive Technology and Smart Education.

[4] Guustaaf, E., Rahardja, U., Aini, Q., Maharani, H. W., \& Santoso, N. A. (2021). Blockchain-based Education Project. Aptisi Transactions on Management (ATM), 5(1), 46-61.

[5] Xu, Y., \& Xiao, N. (2021, March). Research on the Application of Internet Technology in Adaptive Education of Accounting Major. In 2021 2nd International Conference on E-Commerce and Internet Technology (ECIT) (pp. 275-278). IEEE.

[6] Qasim, A., \& Kharbat, F. F. (2020). Blockchain technology, business data analytics, and artificial intelligence: Use in the accounting profession and ideas for inclusion into the accounting curriculum. Journal of Emerging Technologies in Accounting, 17(1), 107-117.

[7] Tharapos, M., \& Marriott, N. (2020). Beauty is in the eye of the beholder: Research quality in accounting education. The British Accounting Review, 52(5), 100934.

[8] Ting, W., \& Liu, Y. (2020). Design and implementation of intelligent accounting data analysis 
platform based on industrial cloud computing. EURASIP Journal on Wireless Communications and Networking, 2020(1), 1-8.

[9] Zhou Shouliang, Tang Dapeng. Transformation and development of accounting education in the era of intelligence [J]. Accounting research, 2019 (12): 3. (In Chinese)

[10] Cheng Yongbo, Eurasia. Whole process dualization: Path Selection of professional degree postgraduate training [J]. 2021 (2018-8): 46-52.(In Chinese) 